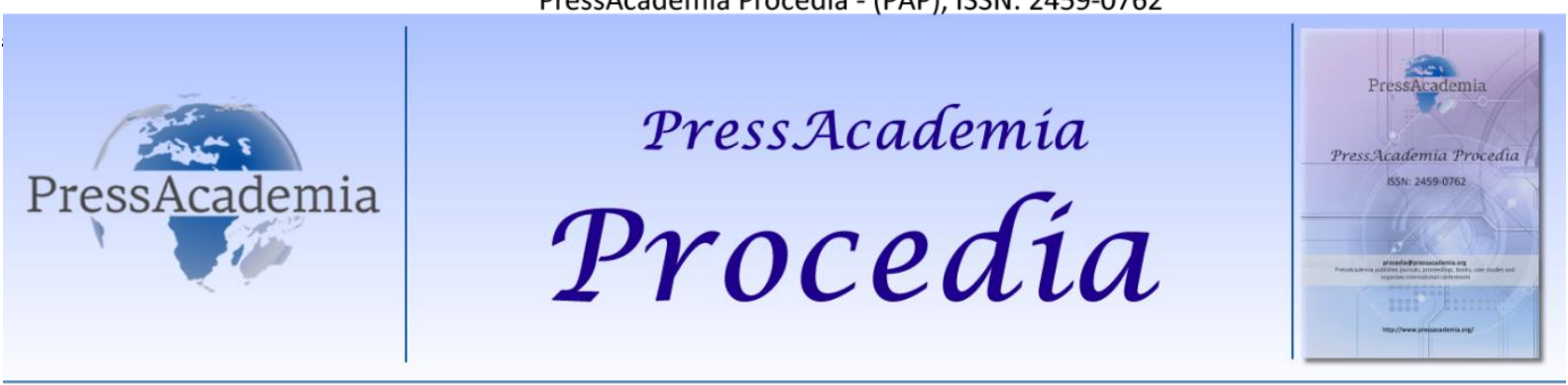

2nd World Conference on Technology, Innovation and Entrepreneurship

May 12-14, 2017, Istanbul, Turkey. Edited by Sefer Şener

\title{
DESIGN AWARDS AS A DESIGN PROMOTION ACTIVITY: INTERNATIONAL DESIGN AWARDS
}

\section{DOI: 10.17261/Pressacademia.2017.528}

PAP-WCTIE-V.4-2017(20)-p.134-142

\author{
Damla Sahin ${ }^{1}$, Alper Calguner ${ }^{2}$, H.Guclu Yavuzcan ${ }^{3}$ \\ ${ }^{1}$ Gazi University, damla.akdas@gmail.com \\ ${ }^{2}$ Gazi University, acalguner@gmail.com \\ ${ }^{3}$ Gazi University, hgyavuzcan@gmail.com
}

\begin{abstract}
Many governments have design policies to increase public awareness level about design and its adding value on products and services. One of these policies are design promotion activities like seminars, exhibitions and publications which are essential to increase the awareness of citizens and companies about the benefits of design. Design awards are one of these design promotion activities that provide companies reputation and publicity. Especially international design awards are significant to promote the product and the company itself in the global context. In this study, design promotion have been identified and the activities belonging to design promotion and the differences between design policy and design support have been revealed. Finally, the role of design awards as a promotion activity have been presented and four design schemes (Design Turkey Industrial Design Award, IF Design Award, Red Dot Design Award, and Good Design Award) have been compared in terms of different dynamics and promotion activities.
\end{abstract}

Keywords: Design, design policy, design promotion, design awards, international design awards JEL Codes: L52; M38

\section{INTRODUCTION}

Design is a powerful tool for nationalities and companies willing to add value to their products or services and to be competitive in both local and global market. However, especially small and medium-sized enterprises (SMEs) are still not aware of the potential benefits of design (Raulik-Murphy and BDes, 2010). This lack of awareness results in low value-added products and services and brings financial failure to both enterprises and nations. In addition, public awareness level about design and its adding value on products and services is also very low. Because of this lack of understanding, many governments have formed and carried out design promotion programmes. These programmes aim to increase awareness of citizens and companies about the benefits of design through design promotion activities like seminars, exhibitions and publications. Design awards are also essential as promotion activity, which provide companies with reputation and publicity. Especially receiving international design award promote the product and the company itself in the global context.

The aim of this study is to identify design promotion and its content, to compare four design schemes (Design Turkey Industrial Design Award, IF Design Award, Red Dot Design Award, and Good Design Award) in terms of different dynamics and promotion activities.

\section{LITERATURE REVIEW}

\subsection{Design Promotion and Design Promotion Activities}

To gain an understanding about design promotion programmes, it is important to research and identify "design promotion" as a term. Activities belonging to design promotion and the differences between design policy and design support have to be also revealed. Despite its popularity as a word, finding a single definition explaning the main activities of design promotion is difficult. There are different opinions about design promotion because it includes many activities different from each other. Sung, Song, Park and Chung (2007) in their paper define design promotion as all activities that to contribute to the progress or growth of design for a nation's sustainable growth'. They divide design promotion into mainly 
two functions: design enlightenment and design support and into eight categories: policy research and proposals, awards and certifications, exhibitions and events, publications and publicity, international exchanges, education and training, research and surveys, and development and aid. On the other hand, Raulik-Murphy and BDes (2010) distinguish design education, design support and design promotion as activitivies that composes the design policy (Figure 1). Support programmes especially focus on businesses, promotion activities on the other hand aim at wider public, generally with the purpose of increasing awareness of the benefits of design by activities such as exhibitions, awards, conferences, seminars and publications. However, design policy is a strategic planning of these all activities to gain maximum advantage (RaulikMurphy and BDes, 2010).

Figure 1. The author's schematic representation of the elements of a National Design System and their definitions (Raulik-Murphy and BDes, 2010)

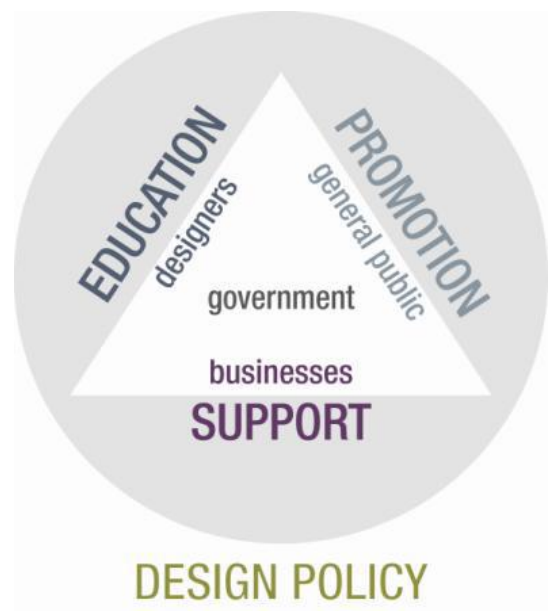

The terms "design promotion and design policy" are generally used interchangeably. In fact, they represent different practices. The former focuses on reducing the awareness of design through activities like seminars, exhibitions, publications and so on; on the other hand, the latter is part of strategic government planning. Design promotion as a term is used instead of design policy by both practitioners and theoreticians ( $E r, 2002)$. However, design promotion is just one of the parts of a design policy (Raulik et al., 2008). Er explains that while design promotion can be presented by non-governmental organisations, policies "require a coordinating power or at least the open support of government to be implemented". In pratical terms, design promotion is easier to apply because it requires less employee training and lower time and finance investment (Raulik-Murphy and BDes, 2010). Therefore, Design promotion programs are more widespread than support programs. According to a recent survey, design promotion is presented in at least 41 countries around the world, while 27 presenting design support. In addition, design promotion programs can reach a larger mass of companies and individuals (Raulik-Murphy, Cawoodand and Lewis, 2010).

Park, Nam and Chung (2010) proposed a new typology for design promotion. They have degraded the classified activities to the two main criteria: 1) Client: private / public sector 2) Method: direct/indirect. It is demonstrated as two axes and four quadrants which include all range of promotion activities. The quadrants are identified as design support, design encouragement, design enlightenment and design furtherance (Figure 2).

Figure 2. Four types of design promotion activities (Park, Nam and Chung, 2010)

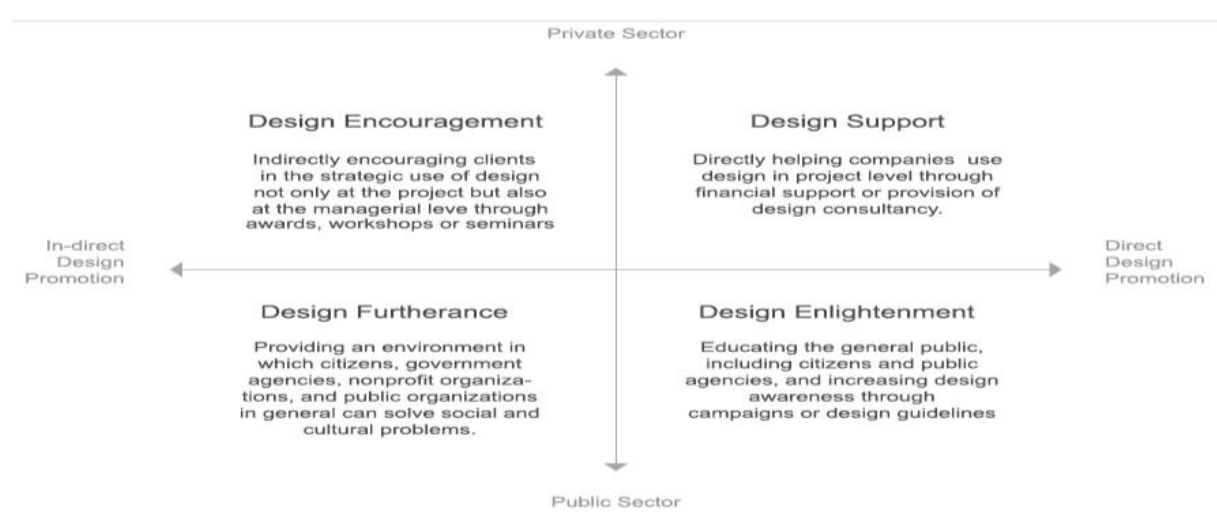


As seen in Figure 2, design support is included in design promotion activities as a direct influencer. Design awards are presented as a piece of design encouragement activities, which is an in-direct design promotion, and the objective of private sector. Design encouragement is defined as "a broder stance in promoting the strategic use of design in companies, pushing for design to be used not only at the project but also at the managerial level." (Park, Nam and Chung, 2010)

\subsection{Design Awards As A Design Promotion Activity}

According to Merriam-Webster English dictionary definition, an award is "a judgment or final decision; especially for the decision of arbitrators in a case submitted to them". Gemser and Wijnberg (2002) define award as:

- It should involve three types of actors (organizers, jurors, and winners)

- It has to be a category of potential award winners and judgement criteria.

- It has to be conferred more than once.

An award not only approves the professional performance of an indiviudual, a group or an enterprise. Sung, You, Lu and Ho (2009) consider that a good award competiton also can distinguish the best form the others and become a dominant selection system in industry. Therefore, due to the rising importance of design, design awards become effective tools for companies and nationalities to be globally visible as a one of the major design promotion activities. Studies prove the benefits of design awards in different aspects. Sung, You, Lu and Ho (2009) have revealed that a world-class design-awardwinning project has better performance on "company reputation" and "free publicity", based on the data collected from 64 of Taiwan's world-class design-award-winning projects (i.e., G-mark, if and Reddot) during the years 2005 to 2007. A study suggested that 'companies that win design awards perform better than the ones that do not', based on an analysis of the financial performance of Japan's Good Design Award winners, and companies (Reinmoeller and Steen, 2004). Research on the values of winning awards have been gathered and presented as a taxonomy by Sung, Nam, and Chung (2010). One of these values is business value which is defined as the potential to create business occasions and to impress clients and customers. Capability value indicates the company's ability on design which builds credibility. Competitive value enables company to outdistance its competitors via awareness of design qualification. If consumers hear about the company's award and become willing to purchase the products, this company gains consumer value. Awards also bring financial value which means better sales, bigger market share, and monetary prizes. Award and its logo could be used in awardwinners' commercials and other material which provides promotion and brings marketing value to the company. Awards also motivate to be creative and innovative via using design, this is defined as organizational value in literature. Winning an award provides visibility of products which brings protection value. Reputation value as competitive value enables to be competitive in market and affects buying decision posivitively. Symbolic value is defined as the value of the award itself (Sung, Nam, and Chung, 2010).

Various stakeholders could gain an advantage through winning a design award (Brunswicker and Seymour, 2006). Designers could have a chance to demonstrate their design abilities by winning design competition.

Design departments of companies also could use the award scheme to prove their design abilities. Winning an award is important for them to survive within the company as a department. After a while, winning a series of awards could become one of the company's strategies (Brunswicker and Seymour, 2006; Lee, 2008).

Design awards bring reputation to company not only in the local market but also in the global market. Awarded products become visible especially with the award exhibitions for overseas buyers, which increases international marketing channels (Lim, 2008).

Awards provide benefits to design consultancies also. They could use awards to convince the clients about their excellent design capabilities (Fuse Project, 2008; Nova Design, 2008; Ziba Design, 2008).

Consumers could be influenced positivitely by awarded products while making purchase decision (Zec, 2007). Therefore, design awards could be strategical element for companies to raise the sales.

One of the example which use design award scheme as a strategically is Samsung. Awards contributed them to be an international brand and a leading corporation in design (Lee, 2008).

\section{COMPARISON OF FOUR DESIGN AWARD SCHEMES}

Four award schemes have both common and different features. Design Turkey Industrial Design Awards is the newest among these four award shemes. The first Design Turkey Industrial Design Awards was implemented in 2008. The scheme received 444 applications and 55 of them are awarded. A total of 410 entries were received in the fourth and the latest Design Turkey Industrial Design Awards scheme in 2014 and 65 entries were given "good design award". The other three 
award schemes (IF Design Award, Red Dot Design Award and Good Design Award), on the other hand, have been implemented for more than fifty years.

In 2016, 5.200 innovations from 57 countries were applied by manufacturers and designers to the Red Dot Award: Product Design. 1,304 products were awaded as "Red Dot" and only 79 entries took the "Red Dot: Best of the Best"; 107 won an Honourable Mention (Red Dot, 2016). IF Design Award scheme received 5,295 entries by 2,458 participants from 53 countries in 2016. From all disciplines (product design, communication design, packaging design, service design, professional concepts and architecture and interior architecture), the IF label was given to 1,821 entries and 75 entries were honored with the coveted IF gold award (IF Design Awards, 2016). A total of 3,658 applications were received in Good Design Award scheme in 2015. 1,337 were honored with Good Design Award and 33 entries received Good Design Long Life Design Award (Good Design Award, 2016). All categories of IF Design Award, Red Dot Design Award and Good Design Award schemes are widely open to manufacturers, consultancies and designers from all over the world.

In Design Turkey Industrial Design Awards, international applications are only accepted for conceptual design awards. The projects, which apply for Design Turkey conceptual design awards, must not have been scheduled to be manufactured and must have been exhibited in a public sphere between the dates determined. Design Turkey Product Design Awards is open to only products designed by Turkish citizens, designed by designers residing in Turkey or design companies registered to a chamber of trade in Turkey, manufactured by companies established according to Turkish Trade Law or Law of Debts and products whose trade mark is registered by companies established according to Turkish Trade Law or Law of Debts (Design Turkey, 2016).

All of four awards have categories, which is divided in different manner. IF Design Awards mainly contains 7 disciplines: product, packing, communication, interior architecture, professional concept, service design and architecture. There are 19 categories under the product design area. The categories of Design Turkey Product Design are similar with IF Product Design, but there are 13 categories. Good Design Awards is divided in six layers as product, space, media, system, activity and front edge. There are 14 categories in product section. Some categories are identified with verb like product for writing/ producing which is different from the other three awards. The Red Dot Product Design has the largest number of categories with 31. While in IF Product Design categories bicycles are in the same category with automobile, in Red Dot Product Design categories there is a category as "bicycle and bicycle accessories". For all of four awards the categories are described in detail with product purpose and usage. The categories for each award are demonstrated in Table 1.

\section{Table 1: Design Award Categories}

\begin{tabular}{|c|c|}
\hline \multicolumn{2}{|l|}{ Design Turkey Product Design Categories (13) } \\
\hline 1. Packaging and Fast Moving Consumer Goods & 8. Urban Products \\
\hline 2. Lighting Products & 9. Sports, Hobby, Game, Toy and Children Products \\
\hline 3. Electronic products & 10. Medical Devices and Equipment \\
\hline 4. Electrical Household Devices and Personal Care Products & 11. Transportation Vehicles and Accessories \\
\hline 5. Home, Kitchen, Office Equipment and Accessories & 12. Sanitary Ware and Building Components \\
\hline 6. Home Furniture & 13. Capital Goods and Machiner \\
\hline \multicolumn{2}{|l|}{ 7. Office Furniture } \\
\hline \multicolumn{2}{|l|}{ Red Dot Product Design Categories (31) } \\
\hline 1. Living rooms and bedrooms & 17. Jewellery \\
\hline 2. Households & 18. Interior design \\
\hline 3. Kitchens, kitchen furnishings and kitchen appliances & 19. Interior design elements \\
\hline 4. Tableware and cooking utensils & 20. Materials and surfaces \\
\hline 5. Bathrooms, spas and personal care & 21. Urban design and public spaces \\
\hline 6. Heating and air conditioning technology & 22. Office furnishings and office chairs \\
\hline 7. Lighting and lamps & 23. Stationery \\
\hline 8. Garden furnishings, garden and BBQs & 24. Industry, machinery and robotics \\
\hline 9. Outdoors, trekking and camping & 25. Tools \\
\hline 10. Sports & 26. Life science and medicine \\
\hline 11. Bicycle and bicycle accessories & 27. Vehicles (land, water and aerospace) \\
\hline 12. Leisure, games and fun & 28. Vehicle accessories \\
\hline 13 Musical instruments and equipment & 29. Consumer electronics and cameras \\
\hline 14. Babies and children & 30. Communication \\
\hline 15. Fashion, lifestyle and accessories & 31. Computers and information technology \\
\hline \multicolumn{2}{|l|}{ 16. Watches } \\
\hline \multicolumn{2}{|l|}{ IF Product Design Categories (19) } \\
\hline 1. Automobiles / Vehicles / Bikes & 11. Home Furniture \\
\hline 2. Sports / Leisure & 12. Kitchen \\
\hline
\end{tabular}




\begin{tabular}{|l|l|}
\hline 3. Babies / Kids & 13. Household / Tableware \\
\hline 4. Watches / Jewellery & 14. Bathroom \\
\hline 5. Audio & 15. Building Technology \\
\hline 6. TV / Cameras & 16. Public Design \\
\hline 7. Telecommunication & 17. Medicine / Healthcare \\
\hline 8 Computer & 18. Industry / Skilled Trades \\
\hline 9. Office & 19. Textiles / Wall / Floor \\
\hline 10. Lighting & \\
\hline Good Design Product Design Categories (14) & \\
\hline 1. Product to be put on a daily basis & 8. Audio/broadcast equipment \\
\hline 2. Product for writing/ producing & 9. Information device \\
\hline 3. Product for cooking & 10. Transportation equipment/facilities \\
\hline 4. Product for learning/ studying & 11. Product for commercial transaction \\
\hline 5. Medical/health/ beauty product & 12. Equipment/ facilities for public space \\
\hline 6. Household goods & 13. Furniture \\
\hline 7. Hobby product / sporting goods & 14. Building facilities \\
\hline
\end{tabular}

The criteria of award schemes are different form each other. Design Turkey criteria are divided in two for good design and superior design. The criteria good design and superior design are similar but the descriptions under these criteria are different. There are mainly six criteria: distinctiveness and innovation, benefits for the user, aesthetics, health and safety, design quality for manufacture and sustainability. Red Dot Product Design evaluates nine criteria: degree of innovation, functionality, formal quality, ergonomics, durability, symbolic and emotional content, product periphery, self-explanatory quality and ecological compatibility. IF Product Design evaluates 11 criteria: design quality, workmanship, choice of materials, degree of innovativeness, environmental compatibility, functionality, ergonomics, visualizationof use, safety, brand value/branding, and universal design. Good Design Award criteria comprise four main viewpoints of human, industrial, social, and time perspectives. Human perspective includes key points like usability, understandability, friendliness, safety, security, environment, sympathy, attractiveness and creativity. Industrial perspective comprises new technology and materials or through creativity, using appropriate technology, method, and quality and the creation of new industry or business. In social perspective, there are keywords like the creation of new culture such as a new method, lifestyle, communication, and the realization of the sustainable society, suggestion about new value, such as a new method, concept, and style. Time perspective includes past contexts and accumulated achievements to propose new value, highly sustainable solution from medium and long-term perspectives and continual improvements in accordance with the times. Except Good Design Award, all of there award schemes select jury members among internationally well-known professionals. Good Design Award judgment committee comprise of Japannese well-known professionals.

The aims of Design Turkey Industrial Design Awards, which is related with design promotion, are "to increase design awareness in the industry and society by promoting award winning designs through award ceremony, exhibitions, publications and press" and "to emphasize the place of Turkey in design world by organising national and international activities". To realize these aims promotional activities are carried out. At first, awards are announced to the press and public through an award ceremony on the opening day of the exhibition. After the jury evaluation finalized, award certificates and trophies are given to the companies and designers of those award winning product designs. Together with the exhibition a conference is organized where academicians and professionals with national and international respectability, are invited and where updated information and approaches are shared. Following the exhibition, awardwinning designs are exhibited in domestic and foreign exhibitions. Award-winning designs and their designers are publicized in the Design Turkey Award Winning Designs Catalogue. Award winning designs are published according to the years, sectors and product types on the web site. Award winners can use the Design Turkey Awards logo in their promotional activities.

IF Design Award declares that, their aim is to strengthen public awareness of design. They organize design-oriented activities with extending the communication network to realize this. Winners can use IF Design Award Logo without any time and area (advertisements, online banners, press releases) limit. In addition, there is the IF ranking logo indicating the position of winner in the IF ranking (Figure 3). 
Figure 3: IF Ranking Logo (http://ifworlddesignguide.com/if-ranking/)

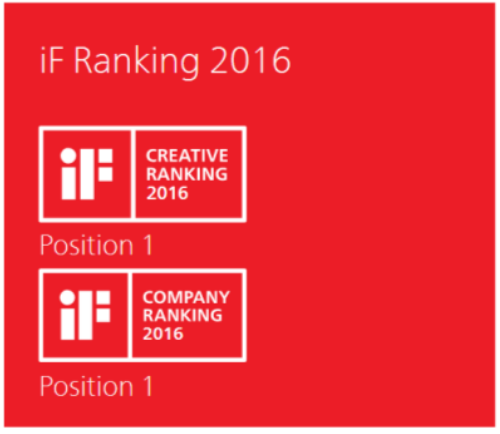

Award-winning designs are presented in IF design exhibition Hamburg. An internet platform exists where awarded designs are featured in. Winners can receive a free profile on this platform. In addition, IF design app, which has iOS \& Android versions, presents award-winning entries of the IF Design Award from the last three years. IF also launches its schedule of international press after the jury session to support the winners' communications. An award ceremony and design party is carried out for award winners as well. Professional photographers take photos, which can be downloaded and used for communication measures. Winners receive certificate during the IF design award night in printed and digital as well. Certificates can be used without any limitations for promotion activities.

The Red Dot Design Award gives the winners certificates during the winners' exhibition and the Designers' Night. "Red Dot: Best of the Best" receive both certificate and Red Dot Trophy. Red Dot Design Yearbook is published which includes awardwinning entries. All products that win the Red Dot are presented for at least a year in The Red Dot Design Museum. In addition, all awarded products are put show on four-week winners' exhibition. "Red Dot: Best of the Best" are staged in the museum's imposing White Hall. The results of the completion are launched international press by the Red Dot communications department. The competition has distinguished media partnerships like ArchiExpo, Design42Day and Yanko Design. The Red Dot App also exists and winners can present their awarded products in the app. Tha app has iOS and Android versions which can be freely downloaded. Additionally, winners of the Red Dot Design Award are able to show their products for a year in Online Presentation platform.

Good Design Award aims to make the society to recognize the idea behind the designed things and to provide the insights for them. Award-winners can use G-Mark logo. Good Design Award winners take an award certificate for each winning application. The winners took Good Design Best 100 and Special Awards are also presented with a trophy (Figure 4). All previous winners are presented in online gallery.

Figure 4.: Good Design Certificate and Trophy (https://www.g-mark.org/about/?locale=en)
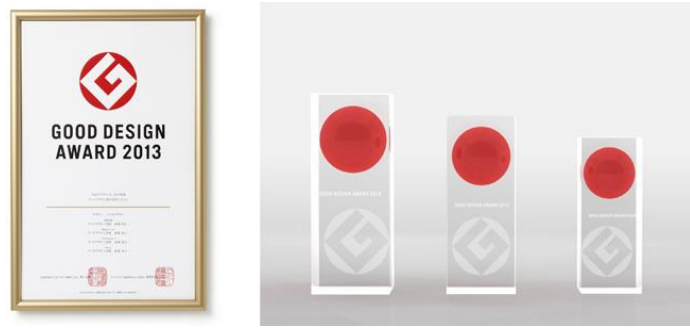

Award winners have opportunity to participate in the G Exhibition, an exhibition of the year's winning designs. Award winners also can attend to the awards ceremony and gather with the jurors. The awarded designs are published in the Good Design Award annual. This award scheme also provides opportunities for being featured in magazines, invited to international exhibitions and trade shows.

The aim of all of four design schemes is to increase design awareness in the industry and society by promoting award winning designs. However, promotion activities to realize this lightly different from each other.

First of all, they have different logo shapes but use the same colors, red and white combinations, in their logos. Red is one of the most used color in brand logos due to its feature of arousing, exciting, and stimulating (Labrecque and Milne, 2012). As seen in Table 2, all of award schemes give winners right to use the logos in their promotion activities which brings reputation to winners in both local and global market. IF Design Award additionally gives IF ranking logo to companies which are within the ranking. 
Figure 5: Design Award Logos

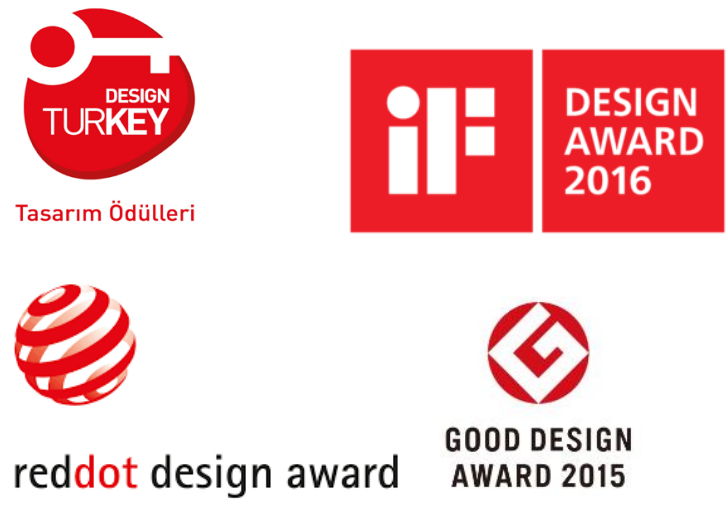

All of four award schemes carry out award ceremony and present the winning entries in exhibition. All of them have their special certificates and thropies. Online platform where the winning entiries and winners are presented exists on all of them. Winners of design awards publicized in four design schemes, either. Only IF Design Award and Red Dot Design Award have mobile applications which include winning entiries. Only IF Design Award and Red Dot Design Award launche international press which supports the winners' communications. Design Museum only exists on Red Dot Design Award scheme. Only Design Turkey Industrial Design Awards organize a conference together with the exhibition where academicians and professionals with national and international respectability.

Table 2: Awards' Promotional Items

\begin{tabular}{|c|c|c|c|c|c|c|c|c|c|c|c|}
\hline & 용 & 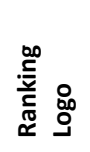 & 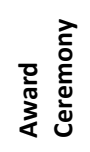 & 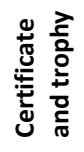 & 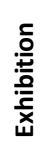 & 趇 & $\frac{0}{\frac{2}{4}}$ & 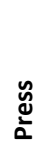 & $\begin{array}{l}\frac{0}{0} \\
\frac{0}{00} \\
\frac{.0}{0} \\
\frac{0}{3} \\
\frac{0}{2}\end{array}$ & 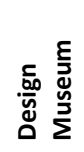 & 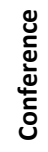 \\
\hline 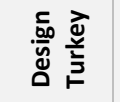 & $x$ & & $x$ & $x$ & $x$ & $x$ & & & $x$ & & $x$ \\
\hline แ & $x$ & $x$ & $x$ & $x$ & $x$ & $x$ & $x$ & $x$ & $x$ & & \\
\hline $\begin{array}{l}\overleftrightarrow{\circ} \\
\stackrel{0}{0} \\
\stackrel{x}{x}\end{array}$ & $x$ & & $x$ & $x$ & $x$ & $x$ & $x$ & $x$ & $x$ & $x$ & \\
\hline 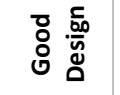 & $x$ & & $x$ & $x$ & $x$ & $x$ & & & $x$ & & \\
\hline
\end{tabular}

Among the top 11 winner companies in IF Ranking 2016 (Philips, Samsung, LG, Sony, Panasonic, Bosch, Phoenix Design, Hewlett Packard, BMW, Apple, and ASUS) 9 of them (Philips, Samsung, LG, Sony, Bosch, Phoenix Design, Hewlett Packard, BMW, Apple, and ASUS) are also winners of Red Dot Design Award and 6 of them (Philips, Samsung, LG, Sony, Panasonic, and ASUS) took Good Design Award, either (Table 3).

Table 3: Companies and Their Awards

\begin{tabular}{|l|c|c|c|}
\hline & IF Design Award & $\begin{array}{c}\text { Red Dot Design } \\
\text { Award }\end{array}$ & $\begin{array}{c}\text { Good Design } \\
\text { Award }\end{array}$ \\
\hline Philips & $\mathrm{x}$ & $\mathrm{x}$ & $\mathrm{x}$ \\
\hline Samsung & $\mathrm{x}$ & $\mathrm{x}$ & $\mathrm{x}$ \\
\hline LG & $\mathrm{x}$ & $\mathrm{x}$ & $\mathrm{x}$ \\
\hline Sony & $\mathrm{x}$ & $\mathrm{x}$ & $\mathrm{x}$ \\
\hline Panasonic & $\mathrm{x}$ & - & $\mathrm{x}$ \\
\hline
\end{tabular}




\begin{tabular}{|l|l|l|l|}
\hline Bosch & $\mathrm{x}$ & $\mathrm{x}$ & - \\
\hline Phoenix Design & $\mathrm{x}$ & $\mathrm{x}$ & - \\
\hline Hewlett Packard & $\mathrm{x}$ & $\mathrm{x}$ & - \\
\hline BMW & $\mathrm{x}$ & $\mathrm{x}$ & - \\
\hline Apple & $\mathrm{x}$ & $\mathrm{x}$ & $\mathrm{x}$ \\
\hline ASUS & $\mathrm{x}$ & $\mathrm{x}$ & \\
\hline
\end{tabular}

\section{CONCLUSION}

Design awards become one of the major promotion activities which provide companies and designers with reputation and publicity. Especially international design awards help companies and products to be globally visible. The studies also support that that 'companies that win design awards perform better than the ones that do not' (Sung, You, Lu and Ho, 2009; Reinmoeller and Steen, 2004). Consumers' buying decision could be impressed in positive way when they come across with the awarded products. This could increase the companies' market share also. In summary, design awards provide many advantages to companies and as seen in table 3, most of well-know companies are aware of the values of winning design award and attend these design award schemes.

In this study four design schemes are compared according to different dynamics like their categories, participation rules, and promotion activities. They have both similarities and differences according to each other. Design Turkey Awards only approves international participators to conceptual design category. Therefore, they could add product design category to increase both the award's and the winners' reputation in global context.

\section{REFERENCES}

Brunswicker, S. and Seymour, R. (2006). 'Surprise! Look who's capturing the value created from a design excellence award'. International Conference on Strategic Innovation and Creativity in Brand \& Design Management, Seoul, South Korea, 29 November 2006.

Design Turkey. Retrived May 15, 2016, from https://www.designturkey.org.tr/

Er, A.H. (2002). Does Design Policy Matter?: The Case of Turkey in a Conceptual Framework. In Lee, S.-I. (Ed.) Design Policy and Global Network. pp.160-191. Seongman: Korea Institute of Design Promotion KIDP \& International Council of Societies of Industrial Design ICSID.

Fuse Project (2008). 'Awards'. Retrieved May 16, 2016, from http://www.fuseproject.com/awards.php

Gemser, G. and Wijnberg, N. M. (2002) The economic significance of industrial design awards: a conceptual framework, Design Management Academic Review, vol. 2, no. 1, pp. 61-71.

Good Design Award. Retrived May 15, 2016, from http://www.g-mark.org/about/

IF Design Award. Retrived May 15, 2016, from http://ifworlddesignguide.com/press-release/791-hannover-26-jan-2016

Lee, S. J. (2008). Manager, Design Planning Group, Corporate Design Center, Samsung Electronics Co. Ltd [telephone interview by W. O. Sung], 29 December 2008.

Lim, M. S. (2008). “'Design Korea” swifts top three major international design awards'. Retrieved 16 May, 2016, from http://article.joins.com/article/article.asp?total_id=3364721

Nova Design (2008). 'News \& awards'. Retrieved May 16, 2016, from http://www.enovadesign.com/news.aspx?WebType=3\&LeftImgID=21 Park, J., Nam, K. Y., \& Chung, K. W. (2010). Promoting design nationally: Influential factors. Design Management Journal, 5(1), 32-39.

Raulik, G., Cawood, G., \& Larsen, P. (2008). National design strategies and country competitive economic advantage. The Design Journal, $11(2), 119-135$

Raulik-Murphy, G., \& BDes, M. A. (2010). A comparative analysis of strategies for design promotion in different national contexts (Doctoral dissertation, University of Wales).

Raulik-Murphy, G., Cawood, G., Larsen, P., \& Lewis, A. (2009). A comparative analysis of strategies for design in Finland and Brazil.

Raulik-Murphy, G., Cawood, G., \& Lewis, A. (2010). Design Policy: An Introduction to What Matters. Design Management Review, 21(4), 5259.

Red Dot. Retrived May 15, 2016, from http://en.red-dot.org/5698.html

Reinmoeller, P., \& Steen, M. V. (2004). Design and corporate performance: Investigating the relationship in Japan. In International Conference on Innovation by Brand and Design Management (pp. 11-14).

Sung, T. J., You, M., Lu, Y. T., \& Ho, S. S. A Study of the Effects of the Type of Design Award on Design Capability and Business Performance. 
Sung, W. O., Chung, K. W., \& Nam, K. Y. (2009). Reflections on design excellence through international product design award schemes. The Design Journal, 12(2), 171-194.

Sung, W. O., Nam, K. Y., \& Chung, K. W. (2010). Strategic use of international product design award schemes. Design Management Journal, 5(1), 72-86.

Sung, W. O., Song, M. J., Park, J., \& Chung, K. W. (2007). Changing roles of design promotion organizations in the global context and a new theoretical model for a design promotion system. Proceedings of the IASDR.

Zec, P. (2007). 'Design on stage - The Red Dot Design Award'. Design Management Review, 18(1), 60-67

Ziba Design (2008). 'News/awards'. Retrieved May 16, 2016, from http://www.ziba.com/NewsEventsAwards. aspx?yr=2008Xia, Y., Singhal, V. R., \& Peter Zhang, G. (2015). Product Design Awards and The Market Value of The Firm. Production and Operations Management. 